\title{
CHANGES SEEN, FORESEEN AND UNFORESEEN
}

\author{
JUSTICE MICHAEL KIRBY*
}

Most lawyers - but I venture to suggest all judges - owe an incalculable intellectual debt to their law teachers. Memories of my days at the Sydney Law School come flooding back: of Dr Currey’s inscrutable mien as he told the marvellous story of English legal history. The disciplined Pat Lane, comfortable in the analytical jurisprudence then so dominant in the constitutional law of the High Court of Australia. The mercurial Frank Hutley, whose unpredictable examination questions on the law of succession were every law student's nightmare. The busy and elegant Gordon Samuels, instructing us in the late afternoons in the niceties of common law pleading. Little did I think I would share the Bench for a time with Hutley and Samuels. The intrepid David Benjafield, ever cheerful. The painstaking Ross Parsons. Bill Morison, whose lectures on torts were models of clarity. The gentle Ilmar Tammelo who did not live to see his beloved Estonia freed from Russian rule. The incisive Tony Blackshield, still at work in his instruction, then a promising acolyte of Julius Stone. And above all "Big Julie" himself, whose profound influence on the Sydney legal scene cannot be overstated. One distinguished judge, hesitant over the recent burst of creativity in the High Court of Australia, asserted to me recently that he could understand it only by reference to the common approach of the Sydney Justices and the influence upon them - directly or indirectly — of the instruction of Julius Stone concerning the judicial function.

I take this occasion to pay tribute to my own law teachers. Instruction in the law never ceases so long as one practises its stern discipline. Every day I continue to be instructed by the passages I 
read, or which are read to me, from judicial and academic writing. Academic texts are used today in courts as never before. Happily (as I am sure you will agree) scholars do not now need to die in order that their works might be acknowledged in court. That was always to require too large a sacrifice which even those passionate for the law might have felt reluctant to pay. Led by the High Court of Australia, the Australian courts are now much more ready to receive and use academic writing from at home and abroad. Ours is an enormous international legal treasure-house. Computers can retrieve a huge mass of data. They can do so in a matter of minutes and from the far side of the world. Judges usually have little time to reflect languidly upon the problems before them. Often they stumble, by instinct or feeling for the law, upon decisions which point them in the right direction. Scholars, typically, have more time to give thought to where the law is, where it is going and where it has gone wrong. Ceaselessly, I press my inquisitiveness upon the barristers who appear in my court. All too often they are captives to the instruction of their faraway days in law school. The only comparative law they know is English law. That is the law which they have in books on their shelves. Whilst this is truly a wonderful source of information and opinion, we should not be hostage to it. At least since Cook v Cook, ${ }^{1}$ Australian lawyers should have realised that no English decision binds them and that no English law has more precedential authority than the law of any other land.

A constant source of guidance and inspiration can be found in the other great courts of the common law. The Court of Appeal of New Zealand, for example, is a most distinguished court. The Supreme Court of Canada and the Courts of Appeal of the Provinces of Canada have so much in common with us that we should use them more often. Especially in the field of commercial law, the decisions of the United States courts bear much useful instruction. So do the opinions of the Supreme Court of India and some of the Caribbean states. Even in Africa, guidance is sometimes to be found, as for example in the decisions of the Supreme Court of Zimbabwe, frequently referred to in that excellent series Law Reports of the Commonwealth. The Appellate Division of the Supreme Court of South Africa has always been a most capable and scholarly court. Lately, we have begun to look 
again at its jurisprudence, especially in the field of commercial law. ${ }^{2}$

So much are legal minds locked into the conventions settled at law school that there is resistance (not only at the Bar table) to demands to look beyond decisions delivered in the Strand. My colleague Justice Meagher, when at the Bar, was once enjoined by me to look beyond the English authorities. I told him that I was sure that I had lately seen cross my desk a decision of the Supreme Court of Florida directly in point: "Your Honour is such a tease", was the rebuke I received.

Lawyers must be sent forth from law schools with a curiosity about the development of legal principle which is global in its sources and free from the self-satisfaction and provincialism that has so often in the past bedevilled our discipline. One of the few disappointments of my judicial life was the reversal of the decision of the Court of Appeal in Osmond v Public Service Board of New South Wales. ${ }^{3}$ The case concerned the right to reasons from administrators. It has always seemed to me, respectfully, that the easy dismissal of the jurisprudence of common law countries other than England, reflected in that decision, was unworthy of a national, final court of appeal. ${ }^{4}$ It is interesting to speculate whether the same approach would have been taken had the question arisen for decision a few years later.

Talk of change in the law and its institutions runs a risk of itself lapsing into chaos. For this is a time of enormous legal change. To stamp a kind of order upon my thoughts, I have divided them like Caesar's Gaul - into three parts. I shall call the parts: changes seen; changes foreseen; and changes not foreseen. I must be wary of the haruspicial pride which overcomes those who predict the future. All too often, they tend to fashion their future world after their own image. They assume that the world which they know will continue. For them the idea of a world unknown to them - worse still without them - is so unsettling as to require rejection. I remind myself of Justice Meagher's recent curial warning in Government Insurance Office of New South Wales $v$ Rosniak ${ }^{5}$ that I should not try to predict the future "like [an] ancient Etruscan soothsayer, examining the entrails of sacrificial birds".

For the venture I accept a perspective of the future of no more than twenty years. Beyond that time the foresight of mankind 
runneth not. Who would have imagined, but twenty years ago, the vast changes which have now come about? The doubling in the number of lawyers and of law schools? The growth of legal megafirms? The development of so many new courts and tribunals? The changes to so much substantive law — including of the common law? Above all the remarkable impact of technology upon the way we do law? Whilst a lawyer of the 19th century would still be relatively comfortable in a courtroom of Australia today generally familiar with its procedures, laws of evidence, dress and courtesies - predicting that this will endure without significant change seems bold in a world of such rapid change. In order to gauge what lies ahead, consider first the changes seen.

\section{CHANGES SEEN}

\section{Institutional Law Reform}

My life in the law has been fortunate. Most judges and many lawyers follow a fairly orthodox path in their professional careers. In mine, I have had the opportunity to work in the Executive Government as well as in the Judiciary, in both branches of the private profession and now in the busiest appellate court of Australia. My period in law reform was tremendously influential upon my development as a lawyer. It helped to reinforce, in practical ways, the lessons which I had received from Stone, Blackshield and Tammelo.

It is nearly a decade since I retired from my post as the first chairman of the Australian Law Reform Commission. Needless to say, I keep a benign eye upon the work of this important national institution. In it, I worked closely with many law teachers. Some of them were foundation members of the Commission — like Alex Castles and Gordon Hawkins. They were the initial Commissioners with Mr (later Sir Gerard) Brennan, Mr (later Senator) Gareth Evans, Mr John Cain (later Premier of Victoria) and myself.

After this inauguration, there was a stream of law teachers serving both as Commissioners and consultants. I came to know many of them. All of them had a great influence upon me. None more than Professor David St L Kelly. It was he, by his imperative daily instruction, who insisted upon the conversion of my mind, at first reluctant, from the pragmatic problem-solving approach which 
the common law encourages, to the conceptual approach preferred by scholars. This latter methodology identifies issues of legal principle and policy and tries to see each problem in the context of a wider mosaic of the law. As a judge and as a citizen I never tolerate denigration of academics generally or of law academics in particular. In my law reform days, it was my privilege to work closely with the legal scholars of Australia. I continue to welcome their instruction.

In institutional law reform there have been many changes. Let me mention first the good news. The Australian Law Reform Commission has not been abolished. This is not a jest. The Canadian Law Reform Commission was wound up recently, despite the protests of the Canadian Bar Association, judiciary and legal scholars. We should not assume that law reform agencies are immune from the envy of competing bureaucracies or short-sighted politicians. Certainly the number of Australian law reform agencies has been cut back. The number of fulltime Commissioners of the New South Wales Law Reform Commission has been slashed. The Victorian Law Reform Commission has been abolished. Selfevidently, the productivity of an agency depends, in part at least, upon the resources and personnel afforded to it.

The Australian Law Reform Commission has had a number of successes in recent times, if success is to be counted by the implementation of reports. Extremely useful reports on such relatively uncontroversial topic as foreign state sovereign immunity $^{6}$ and admiralty ${ }^{7}$ led to prompt federal legislation. ${ }^{8}$ Sometimes a Commission report can lie around for years and then be picked up by a government which finally receives the green light from its bureaucracy or finds itself with an undesired gap in the legislative programme. In Western Australia recently, legislation on the controversial topic of expunge of criminal records was justified, against opposition, by reliance upon a report of the Law Reform Commission? Law reformers have to learn to be patient.

An important innovation has been the better processing of judicial suggestions for law reform. Before I left the Australian Law Reform Commission, its Annual Reports were collecting such suggestions for law reform of interest to federal lawmakers. In this way, judicial criticism of the law channelled, in an orderly fashion, into the legislative process. In New South Wales, Attorney-General 
Dowd instituted a regular system for the orderly review of judicial proposals for law reform. Especially if such suggestions are procedural in character, involve little cost and are otherwise uncontroversial, it is now more likely than not that such suggestions will be followed through. At least a system is now in place. Judges have no entitlement to expect that their suggestions for reform will be automatically adopted. But if they trouble to make them, they surely have an expectation that their perceptions of injustice or inefficiency will command the consideration of the Executive and Parliament.

Perhaps the greatest contribution which can be claimed for the law reform days will be seen, in the light of history, to be the development of a culture of law reform and attention to legal policy. Suddenly there was much more talk about the law, its social function and the policies behind its rules. Lawyers and the community were required to address these issues. The old embarrassment with issues of policy was cast aside and discarded. Indeed the enthusiasm with which many judges and lawyers, late converts, embraced the candid consideration of policy was remarkable. Such a radical change from the analytical jurisprudence of earlier times could not have been achieved without the intellectual leadership of law teachers and of judges who revealed the former "fairytales" for what they were in order to destroy the enduring effects of their legacy. ${ }^{10}$

The Australian Law Reform Commission certainly contributed to this culture of legal change. It is no accident, in my view, that a period of legal innovation in the courts has followed the high publicity and national debates which attended the early work of the Australian Law Reform Commission. Perhaps the demonstration of the incapacity of the legislative system to respond efficiently to institutional law reform in Australia has helped to reinforce the increased willingness of our higher courts to contemplate a renewed role for the judiciary in the orderly reform of the law. This was not an heretical idea. The common law itself is evidence of the capacity of judges of earlier times to produce a large and generally coherent body of principle out of decisions in multitudinous cases. But this body needs constant renewal. Parliament, even as stimulated by institutional law reform, cannot and does not keep pace with that need. The realisation of this fact has imposed new 
obligations upon judges. It has provided opportunities for principled law reform to which law teaching in Australia must be addressed.

Now the bad news. There is less public and professional discussion of law reform today than there was a decade ago. Perhaps in hard times, people are less optimistic. Their priorities may be different. Yet public discussion is itself an important weapon for institutional law reform. It raises expectations which legislators and bureaucrats feel bound to fulfil.

There has been a tendency to deprive law reform agencies of many tasks which, naturally, belong to them. Thus the special committee on criminal law which was established under Sir Harry Gibbs to review federal criminal law, was a task which, institutionally, should have gone to the Law Reform Commission. Perhaps criminal law was thought too close to the interests of the state and its agencies to permit a completely independent scrutiny under close probing public examination. Perhaps the languid pace of some institutional law reform put the bureaucrats off. In the state spheres, there has been a similar haemorrhage of law reform activities to other institutions. Thus, in New South Wales, the Attorney-General now has his own law reform unit within his department. It is under his direct control. It has immediate access to him. Needless to say, its projects tend to get priority of his attention. There is room for a multiplicity of institutions to stimulate legislative law reform. But it would be timely to consider the relative advantages and disadvantages of law reform agencies. If it is felt that they are unable to produce appropriate law reform recommendations, perhaps such agencies or their personnel should be changed instead of looking elsewhere or creating new institutions.

A profound source of disappointment has been the failure of Australian law-making institutions to adapt to the arrival of permanent law reform agencies. At one stage it was thought that such bodies could produce reports which, tabled in Parliament, would have a prima facie expectation of virtually automatic enactment. ${ }^{11}$ This has not come about. Perhaps this is so because of the high controversy attaching to some law reform projects, federal and state. During the Fraser government a system was adopted by which federal law reform reports would be referred automatically 
to the Senate Standing Committee on Constitutional and Legal Affairs. As the Government was bound, by its own policy, to respond to reports of Parliamentary Committees within six months of their delivery, this effectively put a time limit on responses by the Executive Government to proposals of the Australian Law Reform Commission. However, such governmental responses were often uncommunicative. Parliament, distracted by headier political events, usually paid little attention. The blockage in Parliamentary attention to law reform reports is not confined to Australia. Lord Alexander, in a recent speech in the House of Lords, ${ }^{12}$ referred to the special problem presented by the division of responsibilities between different government departments "sovereign in their own fields". Each of these has "orthodox traditions deeply embedded in the thinking of their own officials”. Bureaucratic resistance and parliamentary inertia provide twin impediments to law reform throughout the world. We have not yet found the institutional solutions to overcome these impediments. They represent a serious defect in our lawmaking process. It was an abiding failure of my term in institutional law reform which I hope to live to see corrected.

Finding a place in the crowded legislative programme, designed to meet party political rather than legal priorities, is one obstacle to the orderly processing, of law reform reports. But another is the opposition of powerful interest groups. The Australian Law Reform Commission's outstanding report on its first reference concerning criminal investigation ${ }^{13}$ proposed numerous safeguards against police "verbals" and other manipulation of the evidence of persons in the vulnerable condition of police custody. Had the Law Reform Commission's proposals been implemented in 1975, many of the problems which have bedevilled the administration of criminal justice in Australia (as in England) would have been avoided. It is time that parts of the Law Reform Commission report were picked up by the legislature, generally because they favoured the extension of police powers. The balancing protections for the rights of the accused were omitted. Bereft of proper Parliamentary responses to the Law Reform Commission report (and numerous other reports saying similar things) it was left to the Australian judiciary to move gradually towards the provision of similar judicial checks. In 1977 the High Court of Australia expressly recognised that an unsigned 
police record of interview might be fabricated. ${ }^{14}$ The practical and forensic difficulties of challenging such statements were reiterated by that Court in $1988 .{ }^{15}$ In that year, although the High Court refused to adopt a general rule requiring judges to give warnings to juries, concerning the dangers of convicting a person upon such unsigned records, it was nonetheless held, in the circumstances of one case, that a warning should have been given by the judge in express terms. ${ }^{16}$ In March 1991 in McKinney $v$ The Queen ${ }^{17}$ the Court laid down a new and rigorous requirement which obliges judges to give a warning to juries about the danger of convicting an accused on disputed and uncorroborated confessions to police. Judges are now obliged to do what Parliament had failed to require. This is a serious indictment of the legislative process of law reform in Australia. However, it marks out an important function for the judiciary. It is one which will require skills different from those which were involved in the time of complete and absolute legalism.

There are many other instances where important law reform reports have been left on the shelf because of the objection of powerful interest groups. The defamation report ${ }^{18}$ of the Australian Law Reform Commission is a good illustration. It contains many important reforms to provide remedies for defamation which are more apt to the wrong complained of. These include facilities for a right of reply and for court-ordered corrections. In succeeding guises, the report has been considered by the Standing Committee of Attorneys General over fifteen years - surely a record even for that notoriously dilatory body.

A more recent report of the Law Reform Commission, recommending a code of the law of evidence, ${ }^{19}$ has likewise struck difficulties. It seems that the parliamentary digestion capacity for major tasks of law reform is relatively modest. The best time to get a major project through the legislature is early in the life of a government, when its ministers are fresh and self-confident, can resist the inertia of bureaucracy and sometimes wish to avail themselves of ready-made legislation and the prospect of a notable achievement. This is the way the Australian Commission's reports on insurance contracts ${ }^{20}$ and insurance agents and brokers regulation ${ }^{21}$ passed into law. ${ }^{22}$ Senator Evans, a Law Commissioner turned Minister, gave the reports his blessing and support. That proved enough. Unfortunately, in Australia, as in other countries of 
the common law, law reform reports all too often gather dust. Not much has changed in that regard.

\section{The High Court of Australia}

In the courts, there have been enormous changes in the past twenty years. The changes are most noticeable in the High Court of Australia because it stands at the apex of our legal system and is a source of endless fascination and study for every judge, practitioner and law teacher in this country. The most noticeable changes in our Federal Supreme Court have been physical. The court has moved to its permanent seat in Canberra. For the first time, there is a woman Justice. The title of all Justices has been modified to accommodate this change so that all of the judges are simply "Justice”. "Mr" has been dropped and a common title accepted. Wigs have been discarded. A simple black gown has replaced the regalia of earlier times. The Court is generally younger in appearance and outlook than traditionally it was. It is said that the sight of Sir Edward McTiernan, then in his eighties, as Acting Chief Justice, swearing in the new Senators in Federal Parliament propelled one of the few amendments to the constitution to gain bipartisan support and popular acceptance: the setting of an age limit upon the service of Federal judges in Australia. ${ }^{23}$

Some things do not seem to change. One of them is the New South Wales dominance of the High Court. Now five of the seven Justices derive from that State. It is a misfortune that we have not followed a convention to reflect the diversity of our Federal Commonwealth by appointing judges from different States. It is not as if the profession in different parts of Australia could not provide Justices of distinction. To avoid the embarrassment of naming serving judges, it is enough to say that Chief Justice Bray (South Australia) and Justice Neasey (Tasmania) would have graced the highest Bench. So far, no lawyer from either of those States has ever sat on the High Court. Perhaps Justices should accept appointment for a shorter term, relinquishing such arduous responsibilities upon a principle more rational than the attainment of their seventieth birthday. This might also provide larger opportunities for service. Retired justices, properly pensioned, would be ornaments of grateful law schools - the fate which generally appears to await their equivalents in Canada. 
Other physical changes are immediately noticeable. They include the introduction of video facilities for the conduct of special leave applications across the continent. Those applications have assumed a greater importance since the compulsory acceptance of jurisdiction was replaced by jurisdiction now virtually entirely by special leave of the High Court itself. ${ }^{24}$ The High Court has lately upheld the constitutional validity of the Federal statute which substituted special leave for the previous monetary qualifications for appeals to the High Court. ${ }^{25}$ It is hard to see how the court, absent the facility of special leave, could have coped with the increasingly heavy jurisdiction of appeals if they had remained of right. If the monetary criterion had simply been increased, it would have attached undue importance to large commercial and properly disputes — not always involving a conflict of legal principle of national importance. At least the present arrangement permits the High Court to retain a general superintendence of all Australian courts in all cases. It reserves to the High Court the power to affect the general direction of our law. That is as it should be. But the removal of a large and varied jurisdiction of appeals as of right has undoubtedly changed the composition and character of the High Court's work. It has certainly led to the increase in criminal appeals. This has been criticised in some quarters. But I regard this move as entirely appropriate. Ask the citizen in the street about the comparative importance of different areas of the law. Invariably, the criminal law will be judged the most important. It touches liberty and defines the relationship of the individual to the organised state. The High Court's recently increased attention to criminal cases merely reflects community expectations. For most ordinary citizens the esoteric issues of commercial and properly law would be seen for what they often are: elaborate disputes about debt recovery.

There have been other changes in the High Court which are worth mentioning. One of them is the final termination of appeals to the Privy Council. Although appeals from the High Court itself went years ago, ${ }^{26}$ it was not until the Australia Act 1986 (Cth) S 11 that the final links to the Privy Council were severed. With that severance came Australia's complete legal independence. No longer do judges of this country have to look over their shoulders to the reaction of the Law Lords. Now, we have only ourselves to 
satisfy and to criticise.

Without diminishing our debt to the English judiciary, it is obviously healthy that a country of Australia's size, wealth and legal resources should stand on its own feet. Undoubtedly, this has allowed the High Court in recent years to experiment with the development of legal principle in a way which would not have occurred had the umbilical cord to London remained intact. In an entirely understandable way, the innovations took a time to arrive. They awaited the retirement of judges whose perception of the judicial role and of the function of the courts had been settled at a time when the High Court of Australia still paid obeisance to their Lordships. Finding new principles, new procedures and techniques for the exposition and development of the common law of Australia affords a great challenge to Australian lawyers in the era of legal independence. In answering that challenge, the courts will necessarily look for support and guidance from legal scholars.

\section{State and Federal Courts}

Nor is innovation confined to the High Court. It could scarcely be so. That Court considers about 80 appeals each year. Such a small sample, although selectively chosen, could scarcely satisfy the varied needs of the entire legal system. Choice of cases has itself affected the composition of the sample. There are now few cases about wills, the rule against perpetuities, patents or the niceties of personal property law. Increasingly, the work is criminal, constitutional and concerned with important federal statutes. This fact imposes special responsibilities on the superior appellate courts of Australia. I refer to the Courts of Appeal and Full Courts, federal, territorial and State. Once those courts were kept on a fairly tight rein by the High Court. Their desire to "soar on the wings of policy” was not infrequently checked by judicial rebuke. But no longer.

In Nguyen v Nguyen $^{27}$ the High Court stressed the obligation of federal, territorial and State appellate courts to avoid rigid adherence to principles later considered to have been erroneous. Nothing less was required by the recognition of the comparatively few cases in which the High Court, as a matter of practical reality, could afford redress and correct error: ${ }^{28}$ 
“This Court has never regarded itself as bound by its own decisions, which is all the more appropriate now that it is a court of last resort for all purposes. There is a point view that different considerations should govern the situation of an intermediate court of appeal ....But even if that view were correct, now that appeals to the High Court are by special leave only, the appeal courts of the Supreme Courts of the States and of the Federal Court are in many instances courts of last resort for all practical purposes. ...In these circumstances, it would seem inappropriate that the appeal courts of the Supreme Courts and of the Federal Court should regard themselves as strictly bound by their own previous decisions. In cases where an appeal is not available or is not taken to this Court, rigid adherence to precedent is likely on occasions to perpetuate error without, as experience has shown, significantly increasing the corresponding advantage of certainty."

The reference in Nguyen to the Federal Court of Australia reflects another important development on the Australian legal scene in recent years. The Federal Court, together with the Family Court of Australia, provides a visible federal presence in the daily work of legal practitioners. The fears of wasteful duplication and conflicts of jurisdiction, such as have bedevilled the relations of federal and State courts in the United States of America have receded. The early tendency to confer exclusive jurisdiction on the Federal Court of Australia appears to have been abandoned. Now it is more common to find concurrent jurisdiction: leaving to litigants and those advising them to decide the most appropriate and convenient court in which to sue. This has afforded a degree of competition between courts which can only benefit consumers of legal services, at least in the long run. Whatever remaining fears lingered these have been set at rest by the cross-vesting legislation and the sensible way in which such legislation has been applied both by the Federal Court and by State courts. ${ }^{29}$

Of course, there remain problems. It seems likely to me that, in the long run the Family Court of Australia will become part of the Federal Court. The original idea of a different, more informal court without wigs, robes or open hearings has given way to the return by the Family Court a high measure of orthodoxy and legal form. Many of its problems are extremely difficult. Their importance to citizens of Australia is at least as great as are the other federal jurisdictions conferred on the Federal Court. The desirability and utility of a varied judicial service to avoid prolonged, specialist exposure to one area only of legal practice is another reason for considering a merger. Doubtless there would also be efficiencies 
and cost savings to be gained. Perceptions of status stand in the way. But those are transient perceptions akin to the similar attitudes which once restrained the High Court from entertaining many criminal appeals.

Another change which seems likely in the Federal Court is the eventual establishment of a permanent Federal Court of Appeal. There is such a court in Canada. In the Family Court there are now permanent appellate judges. Experience suggests that the appellate function is different in kind from the trial function. Suggested inconsistencies in decisions of Full Courts of the Federal Court, differently constituted, deprive the conferral on the Federal Court of special jurisdiction in particular federal matters of its principal justification.

Another development of recent times has been the creation of permanent appellate courts in a number of the other jurisdictions of Australia. In Victoria, the Appeal Division was created by the Judges themselves, apparently to fend off the suggested establishment in that State of a permanent appellate court like the Court of Appeal of New South Wales. ${ }^{30}$ The result is a rotating system but with a permanent core of senior appellate judges. In Queensland, a permanent Court of Appeal has been established by legislation. Such a proposal had been discussed for many years. But now it is law. Its first members have been appointed. It too has eased the pain of superseding judges who may have had been appointed to office with a legitimate expectation that they would perform appellate work, by providing a rotating roster for the composition of the Court of Appeal.

The proposal for a national appellate court, under the High Court, advanced by the Constitutional Commission, appears to have got nowhere. But Australia's constitutional inflexibility has sometimes proved to be the mother of invention. It is possible that, by an exchange of judicial commissions, we will see greater mobility in the service of Australian judges in different parts of the country. That mobility will, in turn, reflect greater mobility in the legal profession generally. ${ }^{31}$ For some, it will make judicial service more interesting and attractive. It will permit the sharing of judicial and legal experience in different parts of Australia in ways which were not earlier possible. It will allow the pooling of ideas on judicial technique. Clearly, it is a development to be welcomed. 


\section{New South Wales Court of Appeal}

Despite the rapid increase in the workload of the Court of Appeal of New South Wales, the number of its judges remained unchanged from its establishment in 1965 until 1991. In the same time the workload of the Court increased by $257 \%$. At the end of 1991, with the appointment of Justice Sheller, the number of the Judges of Appeal was increased by one to nine (including the Chief Justice and the President). The appointment of appellate judges with trial experience as judges has been less common in New South Wales than appointment to the Court directly from the Bar or from other courts. ${ }^{32} \mathrm{~A}$ much needed innovation was the appointment of newly retired Judges of Appeal as Acting Judges of Appeal. Thus, Justices Hope and Samuels were at first reappointed by new commissions. They sat, between them, about four or five days a month. This provided a much needed flexibility in the constitution of the Court. It facilitated the composition of multiple divisions of the Court of Appeal. It retained a link with judges of great experience after their retirement; but without imposing on them undue burdens. Another welcome development has been the small increase in the research facility provided to the judges. The Chief Justice has a research officer. So does the Court of Appeal and each of the Divisions of the Supreme Court. It is now common for Judges of Appeal (and some other Supreme Court judges) to appoint recent graduates to their personal staff. There is high competition for such appointments. Last year I received seventyeight applications for two posts on my staff. The graduates eventually recruited came, respectively, from the University of Queensland and the Australian National University, New law graduates recognise the usefulness of a year's service with a judge, seeing the operation of a busy court from the inside.

Amongst the changes in the Court of Appeal's work procedures in my time are the following. The Judges of Appeal, and all of them, now sit regularly in the Court of Criminal Appeal. This follows the procedure adopted in England. It provides a useful integration of the appellate criminal court with the general body of legal principle being applied and developed in the Court of Appeal. ${ }^{33}$ The interaction of expert and non-expert is a common and deliberate feature of the constitution of benches in the Court of Appeal. It is undesirable that any court should lose contact with the 
development of basic legal principle to which, ultimately, the High Court of Australia must bring all Australian courts.

The number, bulk and detail of written submissions to the Court has increased significantly. In certain circumstances the practice of the Court requires a narrative statement of facts to be provided by counsel. This is generally confined to cases of extremely complex facts. It casts on the parties the provision of the first draft of the narrative which would otherwise fall on the judge. The filing of chronologies to assist in the efficient drafting of judgments is also now a standard requirement.

It is my responsibility as President to constitute the Court for particular appeals. This is done in consultation with the Chief Justice. He sits in the Court whenever his other duties allow. The judges have accepted the assignment by me of an obligation to provide (where appropriate) the primary ex tempore judgment or the first draft of a judgment, if reserved. This facility relieves the other judges of the burden of preparing the narrative statement of facts in such cases, unless they elect to do so, as of course they may. Amongst the changes which have occurred in the hearing of appeals is the greater use of Second Reading Speeches and Explanatory Memoranda in aid of the task of legislative construction. ${ }^{34}$ The greater use of academic writing and of policy material (such as law reform and other reports) is also a marked feature of the decade past.

The Judges of Appeal in New South Wales meet every fortnight to review the list of reserved decisions. Each of them explains to their colleagues the state of reserved decisions. This is not only a facility for enhancing collegiality within the Court. By peer pressure, it also tends to be a guarantee against undue delays.

One change in the substantive work of the Court should be mentioned. It arises from the shift in emphasis of decisions of the High Court concerning the advantages enjoyed by trial judges in determining factual disputes. Those advantages have been recognised in a series of decisions, going back a century, both in England and Australia. ${ }^{35}$ But in Warren $v$ Coombes, ${ }^{36}$ the High Court emphasised the obligation of an appellate court, with a legislative obligation to conduct a re-hearing, where necessary to shoulder the responsibility of correcting factual findings which were plainly wrong. 
In a series of more recent decisions, the High Court has placed greater emphasis upon deference to the impact of "subtle influences of demeanour" upon a trial judge. ${ }^{37}$ This emphasis adds a premium to the finality of litigation. It may sometimes cloak serious injustice and prevent its remedy. It appears to give undue weight to impressions of truthfulness of witnesses which are notoriously unreliable in the rather artificial environment of a courtroom. ${ }^{38} \mathrm{It}$ can, in particular cases, effectively neuter the facility of an appeal by re-hearing which Parliament has provided. It has undoubted changed the review of fact-finding by appellate courts in Australia. Presumably it was intended to do so. As "subtle influences of demeanour" may affect most judges in most cases (even if not acknowledged or even referred to) the principle now adopted significantly circumscribes appellate review of many' disputes. In the long term it may diminish the number of appeals, as their utility is seen to be severely limited where facts are in contest.

In the Supreme Court, the changes have been no less radical. The Supreme Court of New South Wales now has a Policy and Planning Committee. It supervises the Court's operations, receives monthly statistical and other reports and considers issues of longrun policy. This committee was established by Chief Justice Gleeson who also determined that the Court should publish an Annual Review. This document now incorporates the Annual Review of the Court of Appeal which had earlier been published as an initiative of the Judges of Appeal.

There are others with greater expertise to speak of the radical changes which have occurred in the trial divisions of the Supreme Court. Clearly, those changes include the decline of jury trial, the establishment of specialist Divisions; the facility to refer issues out for arbitration or report; new cost rules which penalise unreasonable litigation after an offer of compromise has been made, and other rules and procedures designed to promote settlement without litigation. A major experiment on which the Court recently embarked was a "special sittings" of common law cases. Virtually every Judge of the Court, including the Judges of Appeal, sat at various times during a fortnight to help clear the backlog of such cases. Of thirteen hundred cases originally assigned to the sittings, two weeks before it began only five hundred cases were left (the rest being settled or abandoned). The 
remainder were disposed of in less than the fortnight assigned.

\section{CHANGES NOT FORESEEN}

Before I embark upon a number of changes which I foresee in the years ahead, I will acknowledge that bolder spirits may look to more fundamental institutional and legal changes than I think are likely to be accomplished during the balance of my professional life. The approach of a new millennium has, somewhat irrationally, encouraged millennial thinking on the part of some lawyers and other citizens. They dream of the establishment of a republic in the place of the Australian Commonwealth; of the abolition of the States; of the incorporation of a constitutional bill of rights; and a treaty of reconciliation with the Aboriginal people. Some or all of these objects may be achieved. But given the glacial pace which has hitherto marked textual constitutional reform in Australia, this seems unlikely — such is the enduring conservatism of the Australian voter in matters affecting formal constitutional change.

Still others dream of the substitution of features of the inquisitorial system of court procedures, for the adversarial and accusatorial systems which we in Australia have inherited from England. Quite apart from the implications of such a change for judicial training, government funding and our legal culture, it is not self-evident that the change should be adopted. Italy has begun, in reverse, to embrace aspects of the adversarial system out of a sense of disillusionment with the system of judicial inquiry. Many judicial officers in Australia are now much more active in the conduct of proceedings. With the demise of the jury, judges often take a more interrogatory role. Tribunals of great number and variety have been established. Many of these reflect features of the system of inquiry which are typical of civil law countries.

It is possible that wigs and robes will disappear so that all Australian courts (including possibly magistrates) will adopt a simple, black robe as I urged in my Boyer lectures a decade ago. ${ }^{39}$ The High Court of Australia has given the lead. But the States' superior courts (and the Federal courts) seem reluctant to follow. The new Lord Chief Justice of England has predicted the abolition of wigs, at least. He has suggested that it displays a uniform which sends the wrong signals about the functions of the court in a modern society. ${ }^{40}$ If change comes in England, it may be followed 
in Australia. The generation whose concurrence is needed is still profoundly influenced by what happens in London. Yet in these symbolic changes I look for little early progress.

It is now many years since the first women judges were appointed to the Superior Courts of Australia. The Supreme Court of South Australia, ultimately uniformly dropped "Mr" from the title of male judges out of deference to Justice Roma Mitchell. Similarly, when Justice Gaudron was appointed, the High Court of Australia accepted the uniform title of "Justice" - as the Supreme Court of the United States had done shortly before the appointment of Justice Sandra Dey O’Connor. The Family Court of Australia, comprising many female as well as male judges, has ultimately dropped the "Mr". Some judges of the other courts have done so. But the Supreme Court of New South Wales (since Justice Jane Mathews was appointed), the Land and Environment Court (since Chief Judge Mahla Pearlman was appointed), the Supreme Court of Queensland (since Justice Margaret White was appointed) and the Federal Court of Australia (since Justice Deidre O'Connor was appointed) have not resolved uniformly to drop the offending "Mr". Many of the male judges cling resolutely to their ancient title, notwithstanding the differentiation which is thereby established from their female colleagues. If agreement cannot be struck in a matter such as this, the leadership of the superior courts of Australia in things more radical may likewise be elusive.

In substantive law, it seems unlikely that the basic content of our legal system will be deflected far from its English origins. I say this notwithstanding the valiant attempts of the Australian Law Reform Commission to remind judges and other lawmakers of the great change which has come over Australia in recent years, so far as its ethnic composition is concerned. ${ }^{41}$ Perhaps in due course Confucian values will inculcate our legal system and penetrate its principles. Notions of rights may be replaced by a larger emphasis upon duties. The primacy of the individual may give way to emphasis upon the community. The rule of law may even bend to the Confucian ideal of the rule of virtue. But such fundamental changes seem far off. Like the Church and the defence forces, the law and its senior personnel remains noticeably and resolutely Anglo Celtic as the centenary of the Australian Commonwealth approaches. 
The impact of artificial intelligence will undoubtedly be felt in legal practice in the 21st century. It will certainly affect the design of laws. An increasing number of decisions will be fashioned which may be made automatically, without the messy intervention of human judgment. ${ }^{42}$ This too seems far away. Yet in the space of twenty years we have witnessed the impact on the practice of the law and of the courts of multiple photocopiers, word processors, filing by telefacsimile and computer retrieval of legal authority. The future directions of technology promise to assist our discipline in delivering its product to more people more economically.

\section{CHANGES FORESEEN}

\section{Institutional}

A number of institutional changes of an incremental character appear likely to occur. It seems probable to me that more law teachers will be appointed to judicial office in Australia. This has not, until now, been common. Normally, the legal scholar has had to purge the academic experience by a period of legal practice. There are notable and successful illustrations of such appointments. Justices Nygh (Family Court) and Ryan (Supreme Court of Queensland) spring to mind. In New Zealand, the appointment of Professor Grant Hammond, Dean of the Faculty of Law of the University of Auckland, to the High Court produced a predictable reaction on the part of the Bar. But a leavening of experienced and talented legal scholars in the courts is, in my view, highly desirable. Some of the best judges in the United States and in Canada have come from that source. There is no reason of principle why, in Australia, it should be different. With the apparent decline of the other attractions of judicial office to the leaders of the Bar, it seems certain that appointing governments will turn occasionally to academic lawyers.

An abiding weakness of our system of justice is the way it handles unrepresented litigants. Access to the courts by people who cannot afford a lawyer and do not qualify for legal aid is a serious weakness which needs to be addressed. Denying such persons, even where they succeed, their basic costs and out-of-pockets, may uphold the monopolies of the legal profession. But it scarcely represents equal justice under law. ${ }^{43}$ 
I pass over such well worn topics as the increasing use of alternative dispute resolution. The need for procedures for mediation of disputes amongst parties who must continue to live in relation to one another (such as neighbours ${ }^{44}$ and family ${ }^{45}$ ) has repeatedly been referred to in the courts. In such cases the adversarial trial may resolve only the latest symptom of a deepseated problem which remains unresolved. I also pass over the likely increased use of interstate jurisprudence which will follow the realisation of the independence of the Australian common law. In the past, in each State, we have tended to look to London rather than the other States for guidance. Computers will rescue us from this vestige of intellectual colonialism. Of course, the will to be rescued is a prerequisite.

I mention the likely impact of increasing numbers of women upon the practice of law. Some suggest that it will cause the adversarial trial to drop some of its aggressive features. Captives to a special culture, it will take brave women practitioners to do things in different ways. But perhaps some will find that courage. Much more relevant is the escape from attitudes which are difficult to shake off in a profession selected and educated as the legal profession is. Its students tend to be amongst the highest achievers amongst the school leavers. They tend, in turn, to come from homes in wealthier suburbs and from more supportive home environments. In such a catchment, it is more likely to find sympathy for defaulting company directors than for lowly criminals in the thrall of unemployment seeking solace in the escape of mindbending drugs. How we inculcate an appreciation of the variety of our society and the avoidance of monochrome uniformity in its legal culture is a major challenge for the years ahead. Without for a minute endorsing the adoption of "acceptable" attitudes as a new orthodoxy, I do believe that continuing legal education must play a part in teaching lawyers (including judges) about the shifts and changes in the Australian society which they serve. The first faltering steps are being taken for the formal training of judicial officers. It cannot be doubted that these will gather pace.

\section{Procedural}

In the appellate courts it seems likely that strict time limits will be introduced to control the excesses of oral advocacy. Such limits 
have long since been imposed in the United States. They have more recently been introduced in Canada. Necessarily, they tend to shift advocacy from the oral to the written word. This shift has cost implications. It also has political consequences. Less of the court's business is then done in public where the judges, as they judge, may be judged.

To cope with the likely increase in workloads it will either be necessary to keep more people out of court (as by principles upholding immunity from appellate review) or to adopt more efficient procedures for processing appeals. One possibility is the adoption of very short reasons for decisions. This is what the High Court has usefully done in dismissing applications for special leave: necessarily with brief general comments. The Court of Appeal of New South Wales is now, increasingly, doing likewise. Perhaps that technique could be extended. Sometimes in disposing of an appeal it is enough simply to endorse the reasons of the trial judge. Yet deference to the argument of parties normally forces a court to embark upon the provision of its own reasons.

One procedure which may come about in the shift to written argument is the preparation by the parties of a draft of the reasons for judgment which they ask the court to give. The provision of such draft reasons is not entirely heretical. In the New South Wales Court of Criminal Appeal, the Crown has, for a long time, provided a basic draft for the judges. This is supplied to the accused. It sets out the formal details of the trial, the facts proved, the grounds of appeal and the Crown's arguments on these. This document provides a useful basis for the ex tempore judgments without which that Court could not get through its work. Although lacking the repeat players who perform their functions in the Court of Criminal Appeal, it is possible that the Court of Appeal could move, at least in some cases, to a similar procedure in civil appeals. The preparation of provisional reasons, and their distribution to the parties for criticism and comment, is another innovation which may come. It would adapt to the courts the procedures of law reform agencies. So long as the judge has kept a truly open mind to hear the criticism of the parties, it is possible that a better balance between written and oral argument could be constructed: conserving oral submissions to a final attack upon an all-but- final decision of the court. 
Because legal and judicial work has been done in a particular way for a very long time, it is appropriate to pause before changing things long settled. Experience demonstrates that such settled ways often have good reasons to justify them. However, bringing justice to more people who seek it, coping with the ever increasing tide of litigation and operating in an environment of controlled resources, obliges the courts to adopt an attitude of open-mindedness and innovation such as has not been required for the greater part of this century.

\section{Substantive}

There are four substantive areas of the law which I wish to mention. They arise out of recent decisions. They command our attention.

\section{(i) The occasions and limits of creativity}

The first concerns judicial creativity. A series of decisions of the High Court of Australia, during the Barwick and Gibbs Courts, emphasised the strictly limited circumstances in which the judiciary should disturb legal principles found to be "settled". I refer to such decisions as Trigwell ${ }^{46}$ and Dugan; ${ }^{47}$ McInnes $^{48}$ and Osmond. ${ }^{49}$

More lately, however, the High Court of Australia has ventured energetically upon the development of legal principle in numerous areas of the law. The Court would doubtless consider that, in most cases, it has not abolished a settled rule of the common law but merely extended a principle or developed or incorporated it, in a way that is permissible, into a wider general principle. ${ }^{50}$ Many illustrations can be cited of such legal inventiveness. They include Papatonakis v Australian Telecommunications Commission; ${ }^{51}$ Cole $v$ Whitefield; ${ }^{52}$ and Trident General Insurance Co Limited $v$ McNiece Bros Pty Limited. ${ }^{53}$ There have been many other cases. Indeed, 1992 was a vintage year for judicial creativity of the highest importance in the High Court of Australia. ${ }^{54}$ In my own Court the legitimacy of a judge to declare a rule of the common law obsolete because the social conditions upon which it depended have changed fundamentally, was discussed in Halabi $v$ Westpac Banking Corporation. Differing views were expressed. It is extremely rare today to see it disputed that judges have a legitimate function in developing and re-expressing the common law. 
Occasionally, criticism is voiced concerning the extent of judicial creativity. Professor P S Atiyah, for example, has repeatedly emphasised the high desirability of predictability in the common law. ${ }^{55}$ Some of his invocations to a return to the highly technical procedures and pleading of the nineteenth century seem unlikely to command widespread support in Australia today.

The point about judicial creativity is not its existence but its occasions and the techniques to be used where it is considered appropriate. It is here that legal scholars have a special role to play. We should advance beyond the unrewarding debate about whether judges make law. Of course they do. How else would the common law, with all of its complexities, ever have developed? We can even, I believe, advance beyond the issue of whether judges have the legitimacy to unmake a principle of the common law. Let that action be called "further development" and "incorporation into wider general principles” if it makes certain lawyers feel better. If it is then less threatening to the other organs of government, let that rationalisation be adopted, so long as we who are involved in the process - judges and other lawyers - are open-eyed concerning the practical outcomes of what we are doing. There remain the questions of when judges should hold back? When it is appropriate to postpone reform to Parliament (which may never get round to the task)? If creativity is apt, what materials should be available to the judge to ensure that he or she makes the right decision? These are certainly questions worthy of further exploration. No judge, being unelected, has the legitimacy simply to stamp on society an idiosyncratic, personal notion of what the law should be. The law must advance in a principled, rational, logical way so as to serve the changing needs of society. Sometimes it will be appropriate for the judge to decline invitations towards creativity. I have myself done so on many occasions. ${ }^{56}$ On other occasions, "development" of common law principle will be entirely correct. Telling the one case from the other, and doing so in a principled and consistent way which is acceptable to society, presents a topic worthy of legal scholarship and of the most careful reflection by judges.

\section{(ii) Prospective over-ruling}

A like topic is prospective over-ruling. In Oceanic Sun Line Special Shipping Co Inc v Fay, ${ }^{57}$ the High Court of Australia was 
obliged to consider the forum non convenient rule. Justice Deane raised the prospect that, in some cases, the High Court should declare the law to be altered with prospective effect only. ${ }^{58}$ This idea was carried forward in McKinney $v$ The Queen. ${ }^{59}$ There, the High Court established a "rule of practice" "for the future". ${ }^{60}$ It was that a warning should be given by judges to juries about the dangers involved in convicting an accused person on uncorroborated and disputed police evidence of alleged oral admissions. Such prospective rules in respect of criminal law and procedure having widespread potential application for persons already tried and convicted, have been adopted in the United States. ${ }^{61}$ The injustice of such a rule in particular cases has been noted. ${ }^{62}$ However, the course has now been adopted. In some ways it is the natural outcome of the abandonment of the declaratory theory of the judicial function. ${ }^{63}$ The necessity to declare a rule of general operation puts a restraint upon judges who might be tempted to a purely legislative function. The occasions for "prospective over-ruling", and the kinds of cases apt for such decisions remain, in Australia, another subject ripe for future analysis.

\section{(iii) Integrated legal system}

Another area for attention concerns the harmonisation of different segments of the law, Our law is made up of common and statute law, of principles of equity, much subordinate legislation and nowadays some imported rules of international law. There are strong reasons why courts, which must declare, interpret and apply the law as it affects individuals, should seek to harmonise the various components of the law. Specifically there are reasons why common law developments should occur in general harmony with legislative change. I do not regard this as a heterodox opinion. It was stated by no less a judicial personage than Lord Diplock in Warnick $v$ Townend \& Sons (Hull) Limited. ${ }^{64}$ There, his Lordship said: ${ }^{65}$

"Where over a period of years there can be discerned a steady trend in legislation which reflects the view of successive Parliaments as to what the public interest demands in a particular field of law, development of the common law in that part of the same field which has been left to it ought to proceed upon a parallel rather than a diverging course.”

I invoked this principle in Osmond ${ }^{66}$ to justify the development 
from legislative advances in the same field of a common law right to reasons from administrative officials. My attempt was overruled by the High Court. ${ }^{67}$ My present purpose is not to comment again on the particular case. It is to reaffirm my view that judges have a responsibility to seek a rational harmonisation of the different sources of law and of the operation of the rules which make up the obligations imposed on people bound by the law. So far, my attempts to develop this idea have not met with great success. It has been said that Pound's thesis that the common law can be fashioned by analogy with statute has "never really gained general acceptance, at all events in that simple form”. ${ }^{68}$ In an increasingly complex legal landscape legal scholars would do well to revisit this topic. As an extension of my thesis, in Minister for Lands and Forests $v$ McPherson,${ }^{69}$ with the concurrence of Justice Meagher, I suggested that statutes should be interpreted so as to be in consonance with the principles of equity, so long as no unambiguous or contrary intention appeared in the relevant enactment. This is the orthodox approach which is taken to the construction of statutes so as to ensure that they are consonant with basic principles of the common law. ${ }^{70}$ Such a principle is regularly applied by the High Court of Australia and indeed by all Australian courts under it. ${ }^{71}$ There should be renewed attention to perceiving Australian law as it operates in fact. This is not as a set of selfcontained boxes labelled with legal categories. But as an integrated and generally harmonious body of law in the integration of which the courts have a proper function to play.

\section{(iv) International human rights norms}

There is another recent development of the greatest importance. For some years now, I have urged that Australian judges might have regard to fundamental principles of international human rights law in resolving the ambiguities of statutes or in filling a gap where the common law is silent. I have done so in decisions which have sometimes attracted the support of judicial colleagues. ${ }^{72}$ Sometimes the same result is arrived at by others without reference to this notion of drawing upon the developing principles of the international law of human rights. ${ }^{73}$ Until now, the orthodox theory, with special justification in federations of the Commonwealth of Nations, has been that, without specific incorporation by valid local 
statute, such principles of international law are irrelevant to the development of common law rules or the interpretation of ambiguous statutes. ${ }^{74}$ But now the English Court of Appeal has embraced the view which I have been expounding. It is an opinion which is expressed in the so-called Bangalore Principles, adopted by a meeting of judges in which I participated in Bangalore, India in 1988. ${ }^{75}$ Those principles have subsequently been reaffirmed at meetings of Commonwealth judges in Harare, ${ }^{76}$ Banjul, ${ }^{77}$ Abuja, Nigeria $^{78}$ in 1992, at Balliol College, Oxford, and in 1993 at Bloemfontein.

The obvious importance of the approach suggested by the Bangalore Principles for a country such as Australia derives from the absence of a constitutional bill of rights. In England there is no such constitutional bill (save for statutes such as Magna Carta, the Bill of Rights 1688 and the Act of Settlement). But England is now under the discipline of the European Court of Human Rights being (as part of the United Kingdom) a party to the European Convention on Human Rights.

The recognition of the impact of the jurisprudence of the European Court of Human Rights upon English law has now, at last, arrived. It was hinted at by Lord Ackner in the House of Lords in Reg v Secretary of State for the Home Department; ex parte Brind. ${ }^{79}$ It has now been endorsed in the clearest possible terms by the English Court of Appeal in Derbyshire County Council v Times Newspapers Limited. ${ }^{80}$ Lord Justice Butler-Sloss said:

"Adopting ... that approach to the Convention, the principles governing the duty of the English court to take account of article 10 appear to be as follows: where the law is clear and unambiguous, either stated as the common law or enacted by Parliament, recourse to article 10 is unnecessary and inappropriate... . But where there is an ambiguity, or the law is otherwise unclear or so far undeclared by an appellate court, the English court is not only entitled but, in my judgment, obliged to consider the implications of article $10 . .81$

Australia is a signatory to no exactly equivalent treaty. But it is a party to the International Covenant on Civil and Political Rights. That instrument contains many basic statements of human rights akin to those contained in the European Convention. In December 1991, Australia became subject to the operation of the First Optional Protocol to the International Covenant. It did not take long for this development to attract the attention of the High Court of 
Australia. The impact of the International Covenant upon the development of the common law in Australia was noted and indeed called in aid by Justice Brennan (with the concurrence of Chief Justice Mason and Justice McHugh) in Mabo $\mathrm{v}$ The State of Queensland. ${ }^{82}$ There, Justice Brennan said: ${ }^{83}$

\begin{abstract}
"Whatever the justification advanced in earlier days for refusing to recognise the rights and interests in land of the indigenous inhabitants of settled colonies, an unjust and discriminatory doctrine of that kind can no longer be accepted. The expectations of the international community accord in this respect with the contemporary values of the Australian people. The opening up of international remedies to individuals pursuant to Australia's accession to the Optional Protocol to the International Covenant on Civil and Political Rights brings to bear on the common law the powerful influence of the Covenant and the international standards it imports. The common law does not necessarily conform with international law, but international law is a legitimate and important influence on the development of the common law, especially when international law declares the existence of universal human rights. A common law doctrine founded on unjust discrimination in the enjoyment of civil and political rights demands reconsideration. It is contrary both to international standards and to the fundamental values of our common law to entrench a discriminatory rule which, because of the supposed position on the scale of social organisation of the indigenous inhabitants of a settled colony, denies them a right to occupy their traditional lands.”
\end{abstract}

Because it seems unlikely that Australia will get a constitutionally entrenched federal bill of rights in the immediate future it is important that we should not be cut off from the enormous and beneficial developments of human rights jurisprudence which are occurring throughout the world, and specifically throughout the common law countries. The decisions in Derbyshire and Mabo provide a vehicle for ensuring that our courts may develop Australian law in general harmony with the large and beneficial development of international human rights law. To do so will require judges and lawyers who are familiar with that body of law. It will require knowledgeable advocates of courage who will urge these principles upon judges who may at first be reluctant. It will require leadership from the appellate courts: using orthodox judicial techniques for the adaptation of this body of jurisprudence so that it may contribute in the development of our own. The idea that we in Australia, so often the victims of the tyranny of intellectual distance, can "go it alone" indifferent to the worldwide developments of human rights law is unappealing to me. Clearly 
this is an area of the law which deserves the attention of legal scholars both in what they write and in what they teach their students.

\section{EARNING THE TRUST}

I have outlined some of the changes which I have seen in my professional life. The largest hopes for institutional law reform have been dashed on the rocks named Parliamentary indifference appearing close to the bureaucratic empire. Yet law reform bodies still do important work. In the long run their greatest contribution may be seen to have been the encouragement of a culture of legal change and reform. That culture has affected the courts of Australia, including the High Court of Australia and the Court of Appeal of New South Wales. Such courts have changed, institutionally. With the end of Privy Council appeals, they must find their respective places in a national legal system which is still largely derivative. They must increasingly draw upon their own strengths, and upon the ideas of their own members in the years to come.

The Utopian dreams of millennia1 reform seem far away. The prospects of major constitutional changes seem just as remote. Artificial intelligence will undoubtedly affect the delivery of law in the century to come in ways that we can scarcely imagine. But for the moment, there are incremental changes which it seems safe to predict and areas of legal activity which certainly deserve the attention of scholars. I have suggested some of the likely institutional and procedural changes which will come about. I have proposed four topics which deserve particular attention. These are the occasions and limits of judicial creativity of the common law; the occasions and limits of prospective over-ruling of earlier authority; the integrated development of the principles of common law, equity and statute law; and the new province of international human rights law following the accession by Australia to the First Optional Protocol to the ICCPR.

Doubtless every judge and every lawyer could fashion his or her special list of changes seen, foreseen and not foreseen. I have offered mine. Predicting the future is a chancy business. Given the nature of the discipline and the elements of continuity which outlast the centuries, it is perhaps less problematical in the law than in 
most activities of life. For the lawyer of our tradition, looking into the future is as important as looking to the past.

I end as I began. Law teachers provide to their pupils the capital of legal principle which will probably remain with them all their days. They stamp upon the next generation of lawyers the values, attitudes and techniques of the law teachers of today. It is a great responsibility. Law teachers, like judges who are also teachers, must in each generation strive to be worthy of, and equal to, their opportunities.

* President, New South Wales Court of Appeal; former Chair of the Australian Law Reform Commission. This article is adapted from an address delivered to the 47th Annual Conference of the Australian Law Teachers' Association, Brisbane, 11 July 1992.

(C) 1993. (1993) 4 Legal Educ Rev 299.

1 (1986) 162 CLR 376 at 390.

2 IBM Australia Ltd v National Distribution Services Ltd (1991) 100 Aust LR 361 (NSWCA) following Kathmer Investments (Pty) Ltd v Woolworths (Pty) Ltd 19702 SA 498.

3 [1984] 3 NSWLR 447 (CA).

4 See (1986) 159 CLR 656 at 668.

5 (1992) 27 NSWLR 665 (CA) at 699.

6 See Australian Law Reform Commission, Foreign State Immunity, ALRC 24 (Canberra: AGPS, 1984).

7 Australian Law Reform Commission, Civil Admiralty Jurisdiction, ALRC 33 (Canberra: AGPS, 1986).

8 Respectively by the Foreign States Immunities Act 1985 (Cth) and Admiralty Act 1988 (Cth).

9 Australian Law Reform Commission. Spent Convictions, ALRC 37, 1987. Implemented in part, see Crimes Legislation Amendment Act 1989 (Cth).

10 Lord Reid, The Judge as Law Maker (1972) 12 J Public Teachers of Law 22 at 25.

11 A F Mason, Law Reform in Australia, (1971) 4 Fed L Rev 197 at 210f. See Australian Law Reform Commission, Annual Report, ALRC 3 (Canberra: AGPS, 1975) at 20.

12 Noted (1992) 142 New LJ 719.

13 Australian Law Reform Commission, Criminal Investigation, ALRC 2 (Canberra: AGPS, 1975).

14 Burns v The Queen (1975) 132 CLR 258 at 265; Driscoll v The Queen (1977) 137 CLR 517 at 542; Wright $v$ R (1977) 15 Aust LR 305 (HC).

15 Carr v The Queen (1988) 165 CLR 314.

16 Id $337,343$.

17 (1991) 171 CLR 468, (1991) 52 Aust Crim R 240 (HC).

18 Australian Law Reform Commission, Unfair Publication: Defamation and Privacy, ALRC 11 (Canberra: AGPS, 1979).

19 Australian Law Reform Commission, Evidence, ALRC 38 (Canberra: AGPS, 1987).

20 Australian Law Reform Commission, Insurance Contracts, ALRC 20, 
(Canberra: AGPS, 1982).

21 Australian Law Reform Commission, Insurance Agents and Brokers, ALRC 16 (Canberra: AGPS, 1980).

22 Insurance Contracts Act 1984 (Cth); Insurance (Agents and Brokers) Act 1984 (Cth).

23 Constitutional Alteration (Retirement of Judges) 1977. This amendment altered the Australian Constitution S 72. See M D Kirby, Sir Edward McTiernan - A Centenary Reflection (1991) 20 Fed L Rev 165 at 181. Judiciary Act 1903 (Cth), s 35(2) as amended in 1984.

Smith Kline \& French Laboratories (Aust) Ltd $v$ The Commonwealth; Carson $v$ John Fairfax and Sons Ltd (Receivers and Managers Appointed) (1991) 66 Aust LJR 1 (HC).

See Privy Council (Appeals from the High Court) Act 1975 (Cth) upheld in The Attorney General of the Commonwealth of Australia v T \& G Mutual Life Society Limited (1978) 144 CLR 161. See also Privy Council (Limitation of Appeals) Act 1968 (Cth). (1990) 169 CLR 245. Id at 269-270.

See Jurisdiction of Courts (Cross-Vesting) Act 1987 (Cth). Cf Bankinvest AG v Seabrook (1988) 14 NSWLR 711 (CA); NEC Information Systems Australia Pty Ltd $v$ Lockhart (1991) 22 NSWLR 518 (CA) at 530. See M D Kirby Permanent Appellate Courts - The New South Wales Court of Appeal Twenty Years On (1987) 61 Aust LJ 391. Cf Street v Queensland Bar Association (1989) 168 CLR 461.

Cof Wales Court of Appeal is as follows: Gleeson CJ (Bar); Kirby P (Federal Court); Mahoney JA (Supreme Court); Priestley JA (Bar); Clarke JA (Supreme Court); Meagher JA (Bar); Handley JA (Bar); Sheller JA (Bar); Cripps JA (Land and Environment Court); Powell JA (Supreme Court).

33 Sometimes the law in the two courts differs. See eg $R v$ Masters (1992) 26 NSWLR 450, (CCA) 59 Aust Crim R 445, (NSWCLA) where the NSW Court of Criminal Appeal declined to follow the Court of Appeal decision of Australian National Industries Ltd v Spedley Securities Ltd (In Liq) (1992) 26 NSWLR 411 (CA). See discussion Re Bolton; ex parte Beane (1987) 162 CLR 514 at $517 f$. See eg SS Hontestroom v SS Sagaporack [1927] AC 37 (HL) at 47 and cases there cited.

36 (1979) 142 CLR 531.

37 The cases are collected in Dawson v Westpac Banking Corporation (1991) 66 Aust LJR 94 (HC). They include Brunskill v Sovereign Marine \& General Insurance Co Ltd (1985) 59 Aust LJR 842 (HC) at 844; Jones v Hyde (1989) 63 Aust LJR 349 (HC) at 351; Abalos v Australian Postal Commission (1990) 171 CLR 167 at 178.

See eg Chambers $v$ Jobling (1986) 7 NSWLR 1 (CA), 9; cf Warren $v$ Coombes (1979) 142 CLR 531 at 537.

39 M D Kirby, The Judges, Boyer Lectures, 1983, ABC, 79.

40 Lord Chief Justice Taylor quoted The Times, April 271992 at 1.

41 Australian Law Reform Commission, Multiculturalism and the Law, ALRC 57 (Canberra: AGPS, 1992).

42 See R E Susskind, Artificial Intelligence, Expert Systems and Law [1990] Denning Law J 105; A Kowalski, Leading Law Students to Unchartered Waters and Making Them Think: Teaching Artificial Intelligence and Law (1991) $2 \mathrm{~J}$ Law Info Sc 185. 
The reference is to Cachia v Haines (1991) 23 NSWLR 304 (CA).

Hemmes Hermitage Pty Ltd v Abdurahman (1991) 22 NSWLR 343 (CA) at 351.

Tsivinsky v Tsivinsky, (Court of Appeal (NSW), unreported, December 5 1991; (1991) NSWJB 149.

State Government Insurance Commission v Trigwell (1979) 142 CLR 617.

Dugan v Mirror Newspapers Limited (1978) 142 CLR 583.

McInnis $v$ The Queen (1979) 143 CLR 575. See now Dietrich $v$ The Queen (1992) 177 CLR 292.

Supra note 4.

See discussion Halabi $v$ Westpac Banking Corporation (1989) 17 NSWLR 26 (CA) at 57.

(1985) 156 CLR 7 (liability to invitees and other entrants on to property).

(1988) 165 CLR 360 (Australian Constitution, s 92).

(1988) 165 CLR 107 (third party contracts).

See eg Australian Capital Television Pty Ltd $v$ The Commonwealth (1992) 66 Aust LR 214 (HC) (implied constitutional recovery of monies paid under a mistake of law); Domican v The Queen (1992) 173 CLR 555 (identification evidence); Mabo v Queensland (1992) 175 CLR 1 (native title); Williams $v$ Spautz (1992) 174 CLR 509 (tort of malicious procedure); and Dietrich supra note 48 (right to counsel).

See P S Atiyah, Justice and Predictability in the Common Law (1992) 15 UNSWLJ 448. Cf M D Kirby, In Praise of Common Law Renewal (1992) 15 UNSWLJ 462.

See eg Citicorp Australia Ltd v Hendy (1985) 4 NSWLR 1 (CA) at 23.

(1988) 165 CLR 197. Cf Bropho v Western Australia (1990) 171 CLR 1 at 2325; Peters v Attorney-General (NSW) (1988) 16 NSWLR 24 (CA) at 38; 37 Aust Crim R 102 at 113. Note K Mason, Prospective Overruling (1989) 63 Aust LJ 526.

(1988) 165 CLR 197 at 257. Another illustration of the adoption of an arbitrary rule of general application is to be found in Todorovic $v$ Waller (1981) 150 CLR 402.

(1991) 171 CLR 468; 52 Aust Crim R 240 (HC). For discussion see M D Kirby, Miscarriages of Justice - Our Lamentable Failure? (1991) 17 Cwth L Bulletin 1037.

See id 476; 245.

See Reg v National Insurance Commissioner; Ex parte Hudson [1972] AC 944 (HL) at 1026; Miliangos v George Frank (Textiles) Ltd [1976] AC 443 (HL) at 490 but cf Lord Mackay, Can Judges Change the Law? (1987) Proceedings British Academy, 285 at 306; see Lewis Retrospective and Prospective Rulings in Administrative Law [1988] Public Law 78. As to United States cases see Mapp v Ohio (1961) 367 US 643; Linkletter v Walker (1965) 381 US 618.

$R v$ Sums (1991) 55 Aust Crim R 241 (NSW CCA) at 292.

M H McHugh, The Law-making Function of the Judicial Process (1988) 62 Aust LJ 15.

[1979] AC 731 (HL).

Id at 743 .

(1984) 3 NSWLR at 465.

(1986) 159 CLR 656 at 669.

See eg Cotogno v Lamb [No 3] (1986) 5 NSWLR 559 (CA) at 570. But see (1987) 164 CLR 1 at 11.

(1991) 22 NSWLR 687 (CA). See also Wickstead v Browne (1992) 30 NSWLR 
1 which deals with the relationship of common law and equity. Cf G Lewis, Lord Atkin (London: Butterworths, 1983) 78.

70 See eg Byles J in Cooper $v$ Wandsworth Board of Works (1863) 14 CBNS 180 at 194-195; 143 ER 414, at 420.

71 See eg Commissioner of Police v Tanos (1958) 98 CLR 383, 395; Yuill v Corporate Affairs Commission of New South Wales (1990) 20 NSWLR 386 (CA) at 402.

72 See Gradidge v Grace Bros Pty Ltd (1988) 93 FLR 414 (NSWCA).

73 See eg Daemar v Industrial Commission of New South Wales\& Ors (1988) 12 NSWLR 45 (CA); 79 Aust LR 591 (NSWCA); S \& M Motor Repairs Pty Ltd v Caltex Oil Australia Ltd (1988) 12 NSWLR 358 (CA); Jago v District Court of New South Wales (1988) 12 NSWLR 558 (CA); Cachia v Haines (1991) 23 NSWLR 304 (CA) at 312.

74 See discussion in Dietrich $v$ The Queen (1992) 177 CLR 292 at 306, 307 where the relevant Australian and English authorities are collected. See especially Koowarta v Bjelke-Petersen (1982) 153 CLR 168,200.

7514 Commonwealth L Bull 1196; (1988) 62 Aust LJ 531.

7615 Commonwealth L Bull 999.

77 See Commonwealth Secretariat, A Third Colloquium on the Domestic Application of International Human Rights Norms, London, 1991, l at 3.

78 See Commonwealth Secretariat, Developing Human Rights Jurisprudence, 1991,15.

79 [1991] 1 AC 696 (HL) at 747, 760. See also Lord Goff of Chieveley in Attorney General v Guardian Newspapers Limited (No 2) [1990] 1 AC 109 (HL) at 289.

80 [1992] 3 WLR 28.

81 Id at 60.

82 (1992) 175 CLR 1. See comment P Bayne (1992) 66 Aust LJ 844, at 845.

83 Id at 42. 